\title{
Translation of Good in The History of Tom Jones, a Foundling
}

\author{
Mahbube Noura ${ }^{1}$ \\ ${ }^{1}$ School of English Language, University of Zabol, Zabol, Iran \\ Correspondence: Mahbube Noura, School of English Language, University of Zabol, Zabol, Iran. E-mail: \\ nouramahbube@yahoo.com
}

Received: March 5, 2012

Accepted: April 23, 2012 Published: June 1, 2012

doi:10.5539/ijel.v2n3p49

URL: http://dx.doi.org/10.5539/ijel.v2n3p49

\begin{abstract}
Following Newmark, "often, though not by any means always, translation is rendering the meaning of a text into another language in the way that author intended the text" (Newmark, 1988: 5). To accomplish this, finding appropriate and natural equivalents is of prime importance and for the translator; collocation is the most important contextual factor which usually affects translation. So, recognizing whether or not a collocation is familiar or natural is one of the important problems in translation. The Word good because of its broad collocational range, may have different equivalents in different contexts. This paper investigated the different equivalents of the word in the Persian translation of the English novel The History of Tom Jones, a Foundling. In order to fulfill the research purpose, all the instances of the word good, by means of AntConc concordancer and their Persian equivalents were extracted. After collecting data, they were classified and analyzed. Analysis of the data showed that translator, nearly in most cases, aimed at using established and typical equivalents. The study finally comes up with the conclusion that accuracy is no doubt an important aim in translation, but it is also important to bear in mind that the use of common receptor-language patterns which are familiar to the target readers plays an important role in keeping open the lines of communication
\end{abstract}

Keywords: translation, the English, the Persian, collocation, equivalents

\section{Introduction}

By dictionary definition ,translation consists of changing from one state or form to another ,to turn into one's own language (Merriam-Webster Collegiate Dictionary, 2006).In Newmark's words, "often, though not by any means always ,translation is rendering the meaning of a text into another language in the way that the author intended the text" (Newmark, 1988: 5). We may think that this rendering ought to be simple, as one ought to be able to substitute a word in the source language with another one in the receptor language. But, translation is not simply substitution of lexical items in the two languages. The translator, in the process of translation, is constantly looking for the most appropriate and natural lexical equivalents between the source and the receptor language. Following Nida, "naturalness" is a key requirement of a translation. Indeed, he defines the goal of dynamic equivalence as aiming at "the closest natural equivalent to the source language message" (Nida, 1964a: 166; Nida, \& Taber, 1969: 12). The source language text may use a generic word, but the receptor language may have more specific words in that semantic area, as well as a generic word. Use of the more generic word might not be appropriate for that context, On the other hand, if one is translating, one would need to evaluate each context to decide which term would be the best choice in the receptor language, for "a word 'acquires' meaning through its context"(Munday, 2001: 38). Furthermore, the choice will depend on the collocational range of each of the equivalents. According to Newmark "translation is sometimes a continual struggle to find appropriate collocations, a process of connecting up appropriate nouns with verbs and verbs with nouns, collocating appropriate adjectives to the nouns and adverbial groups or adverbs to verbs"(Newmark, 1988: 213).

As an example, good is a generic English word. Suppose Persian as the receptor language, it is not always correct to use generic equivalents "خوب"for this English generic word. Concerning the context and the collocational range of this generic word, a translator should choose the best lexical equivalents and does not confine himself to referential meaning.

As lexical equivalents for generic words is concerned, it is a problematic issue in the field of translation and finding the closest natural equivalent is of prime importance. Recognizing whether or not a collocation is familiar, 
natural, or just acceptable, is one of the most important problems in translation. However, it is believed no research has yet been done on this topic.

\subsection{Significance of the Study}

This study is an attempt to identify and categorize different equivalents of the English word good in the Persian translation of the English novel The history of Tom Jones, a Foundling. Hopefully, the findings of this research have an influential role in lifting translators' problems. Also, its results can be fruitful for translation students, teachers, classes and anyone who is working on translation. It is hoped that it creates sensitivity toward looking for the suitable equivalent way to express the meaning in the receptor language and translating as naturally, accurately and with maximum effectiveness as possible.

\section{Method}

As it was mentioned previously, an English novel by Henry Fielding, entitled The History of Tom Jones, a Foundling (1749) and its Persian translation by Karimi Hakkak, have been selected as the literary source texts. It is one of the great masterpieces of English literature and a major force in the development of the novel form. This novel has been selected from among seventeen English literary works. The e-book of these literary works loaded in AntConc software, which is a freeware concordance program, and the freeware processed them. The result of the texts processed showed that the number of the English word good in the above said novel were more than in the other novels. It is worth mentioning that there are some limiting conditions which restrict generalization of the results: because of time limitation only one literary work of eighteenth century has been selected and in fact there has been no randomization in the selection of the research's sample.

\section{Results}

The data which were collected then were analyzed to accomplish the purpose of the study. The following classification summarizes the results of the study on the different equivalents of the English word good.

\subsection{Good}

Data which are included here are classified into five categories.

3.1.1 This category is the classification of those data in which the word good is an adjective (In $59.50 \%$ of data, good serves as an adjective). Within this category we have seven subcategories.

\subsubsection{Of Persons}

Here good refers to a person $(44.60 \%$ of adjective good). According to the grammatical structure, six groups are defined.

3.1.1.1.1 Good + person have been translated as an adjective + person. According to equivalent adjective which translator has used, data are classified into 3 groups.

\subsection{Cultural Equivalent}

For example:

E: she's a true good lady (p. 330)

P: راسي راسي خانوم ماهيد (ص.398)

\subsection{General Adjective}

For example:

E: that's a good girl (p. 615)

P: اينو ميكن دختر خوب (ص.764)

\subsection{An Unmarked Equivalent}

Translator, according to the context and collocational range of words, has used a typical equivalent for good.

For example:

E: the good woman gave Black George to the evil (p. 200)

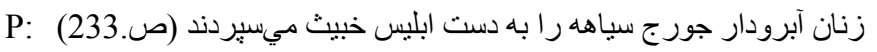

E: the good lady could not forbear (p. 24)

خانم نيكو خصال نتو انست خودداري كند (ص.10) (p) 
3.1.1.1.2 so/this/that/ the + good + (a) + person has been rendered as a proper noun. Translator has selected this proper noun according to the context.

For example:

E: nor did that good lady depart without learning some wholesome admonition (p. 185)

P: خانم وسترن اين موقعيت را بلا استفاده نكذاشت (ص.212)

3.1.1.1.3 Good + person has been rendered as person + noun. Here, the equivalent of adjective good is a noun which indicates the profession of that person and has been selected according to the context.

For example:

E: after the departure of that good woman (p. 318)

P: بعد از خروج زن مهمانخانهاد از اتاق (ص.

3.1.1.1.4 Good + noun indicating persons and their professions have been translated as an adjective+ noun.

For example:

E: having behaved himself always like a good valiant soldier (p. 241)

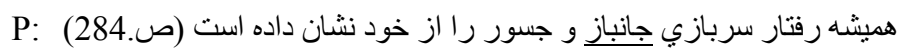

E: good writers will, indeed, do well (P. 379)

P: راستي را، نويسندكان جيره دست نيز بايد (ص.462)

3.1.1.1.5 Good + person have been translated into a noun.

For example:

E: He knew the nature of that good man (p. 154)

P: ميدانست كه نهاد اين نيكمرد (ص.148)

E: I am sure we are very good friends to the government (p. 234)

P: ما كه خدمنكز ار اين حكومتيم (ص.275)

3.1.1.1.6 Determiner "the" + good have been translated in to a plural noun.

For example:

E: even to the good (P. 611)

P: حتي نيك سرشتان (ص.758)

3.1.1.2 Of qualities or attributes (38.40\% of adjective good refer to qualities or attributes). Data in this category are classified into 13 groups.

3.1.1.2.1 Of actions, intentions, offer, offices, opinion, principals, qualities and wishes.

For example:

E: for this one good action forgive her all her sins (p. 600)

P:به خاطر همين يه كار نيك همه كناهانشو بيخشه (ص.743)

E: you are sincere in such good intentions. (p. 597)

P: شما در اين نيت صصواب خودتون بابرجاو استو اريد (ص.739) (pol)

E: a lecture to the person on good manners (p. 501)

P: مو عظاتي خطاب به كثيش در باب آداب معانشرت (ص.617)

E: it was not so good an offer (p. 560)

P: بيشنهاداون شخص تاين اندازه هشمكيرنبود (ص.693)

E: the good offices which that grateful fellow had promised (p. 533)

P: خدمات مفيدي كه اين مرد قدرشناس قول داده بود (ص.658)

E: For the good opinion he had professed of his nephew (p. 171)

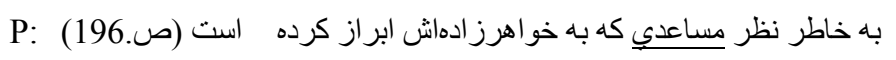

E: among other_good principals (P. 492) 
P: در ميان ديكر اصول حسنهاي (ص.606)

According to Persian equivalents which translator has used, in this category data are classified into 3 groups.

3.1.1.2.1.1 Good + nouns in 1.1.2.1 has been translated into an adjective + noun.

For example:

E: you good intentions (p. 534)

P: نيت خيرخو اهانه شما (ص.658)

3.1.1.2.1.2 Good + nouns in 1.1.2.1 have been translated into a noun.

For example:

E: I am certain he hath many good qualities (p. 603)

P: اطمينان دارم محسنات بسياري داره. (ص747)

3.1.1.2.1.3 To conceive/to have + good + opinion has translated into a verb.

For example:

E: waters had in truth, not only a good opinion of our hero (p. 313)

P: خانم و اترز نه تنها از قهرمان ها خوشش آمده بود (ص.375)

\subsection{Of Immaterial Things}

For example:

E: who hath generally a good nose (p. 91)

P: كه معو لا شامه تيزي دارند (ص.95)

E: the squire gave him a good curse at his departure (p. 114)

P: ارباب فحش آبداري بدرقه راه تام كرد (ص.122)

\subsection{Of Fortune and Luck}

According to Persian equivalents that translator has used, we have 3 groups.

3.1.1.2.3.1 To have + (the) + good + luck or fortune has been translated into an adverb.

For example:

E: he had the good fortune to prevent. (p. 326)

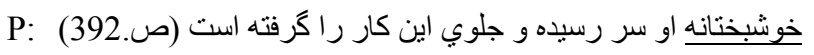

3.1.1.2.3.2 Good+ fortune /luck has translated into an adjective + noun.

For example:

E: betokens much good fortune. (p. 259)

P: حكايت از بخت و اقبال خوش داره (ص.310)

3.1.1.2.3.3 To have + (the) + good + luck / fortune has translated into a sentence.

For example:

E: he had the good fortune to miss his men (p. 239)

P: بخت ياري كردو تير به هدف نخورد (ص.281)

3.1.1.2.4 Of News, Night and Journey

For example:

E: well, but what is your good news (p. 519)

P: خوب حالا خبر خوشت جِيه (ص.640)

E: wished his companion a good night (p. 410)

P: براي هميياله خود شب خوشي را آرزو كرد (ص.504)

E: a good journey (p. 34)

P: سري خوش (ص.23) 


\subsection{Of Health and State of Mind}

For example:

E: your honor is seemingly in perfect good health (p. 420)

P: شما ظاهر أصدرصد سالم و سرحالين (ص.515)

E: which a good mind enjoys (p. 410)

P: كه نشون دهنده ذهني آراجو نيك انديثه (ص.503)

\subsection{Of Material Things}

For example:

E: a good blade (p. 237)

P: تيغهاي برا (ص.279.)

E: not to part one good thing (p. 574)

P: نميخواست يك جيز قيمتي را از دست بدهد (ص.710)

3.1.1.2.7 Of Security, Reason, Authority

According to Persian equivalents that translator has used, two groups are defined.

3.1.1.2.7.1 Good + security/ reason/ authority has rendered into an adjective + noun.

For example:

E: might be called pretty good security (p. 48)

P: ميتوان وثيقة بسيار معتبري ناميد (ص.40)

E: for some other reasons equally good (p. 216)

P: دلايل قانع كننده ديكري در كار بود (ص.253)

3.1.1.2.7.2 A preposition + good + security / reason/ authority has been translated into an adverb.

For example:

E: he was with good reasons offended at the treatment he received (p. 266)

P: حقًا از رفتاري كه كد بانو ثبت به او در بيش كرفته بود سخت آزرده خاطر شد (ص.218)

3.1.1.2.8 Of Book, Advice, Lesson

For example:

E: may learn one good lesson (p. 115)

P: يك درس بسيار مفيد را مي/آموزد (ص.124)

\subsection{Of Fame and Reputation}

\section{For example:}

E: the house is well known to be a house of good reputation as any on the read (p. 310)

P: مهونخونه ما توي مهمونخونهاي سر راه جاي آبرومنديه (ص.371)

\subsection{Of Purpose and Effect}

For example:

E: to many good purposes (p. 31)

P: در راه هدفهاب متعالي بسيار (ص.19)

E: must at least have this good effect (p. 210)

P: دست كم اين فايده را در بر دارد (ص.246)

\subsection{Of Countenance and Teeth}

For example:

E: a good countenance is a letter of recommendation (p. 274)

P: يك جهره خوشايند كار يك توصبه نامه را ميكند (ص.329) 
E: he had good teeth. (p. 36)

P: دندانهاي درخشاني داثت (ص.25)

\subsection{Of Family}

For example:

E: enquire after the good family (p. 264)

P: از روز و روزكار اين خانو اده شريف جويا شد (ص164)

\subsection{Of an Animal}

For example

E: have are two or three good horses in the stable (p. 337)

P: اينجا هم دوسه نا اسب قبر اق توي اصطبلثون هست (ص.406)

\subsubsection{Of Things}

Within this category 2 groups are classified.

\subsection{Of Food and Drink}

For example

E: with a tankard of good ale (p. 90)

P: يك ليوان بزرك آبجو اعلا (ص.93)

\subsection{Of a Place}

For example:

E: I have several good rooms for that matter. (p. 330)

P: جندين و جند اناق خبلي شيك داريم (ص.397)

E: kept a good house (p. 19)

P: خانهاب منظم و مرتب داشت (ص. (5) (19)

\subsubsection{Good in the Address Form}

In this category adjective good comes before the names of persons whom have been addressed.

For example:

E: good Honour, let me know it without any longer preface (p. 214)

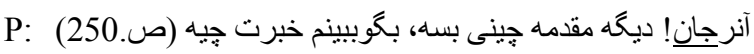

E: my good friend (p. 290)

P: دوست عزيز (ص.348)

3.1.1.5 Those data in which we have determiner "a"+ good + deal (of) are classified under this category.

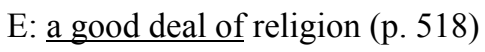

P: دينداري و افر (ص.638)

3.1.1.6 In this category, adjective good is applied to god, sometimes in the wide sense, as containing moral perfection generally, and sometimes with more restricted reference to his benevolence and in exclamation containing the name of god or some substituted expressions as good god! good lord! and good heaven!.

For example:

E: good heavens! (p. 594)

P: بار الها (ص.736)

3.1.1.7 Idiomatic Expression Good- Lack- a-day

For example:

E: good-lack-a-day (p. 233)

P: بعله ، ديخه (ص.274) 
3.1.2 In this category, the word good serves as a noun (good as a noun constitute $5.74 \%$ of all the data).

For example:

E: for the good of my family (p. 502)

P: به خاطر مصالح خانو اده (ص.618)

3.1.3 This category involves the combinations of the word good with nouns such as sense, nature, breeding, will, humor and temper (14.23\% of all the data are the combinations of good). According to Persian equivalents that translator has used, data are classified into 5 sub categories.

3.1.3.1 Those data in which good + aforesaid nouns has translated into a noun.

For example:

E: her good humor deserve so much commendation (p. 546)

P: خوشر ذوقي فلان كس جاي اينهمه ستايش دارد (ص.674)

3.1.3.2 Good + aforesaid nouns has translated into an adjective. In Persian equivalent adjectives are called compound adjectives.

For example:

E: this was accorded with more good - will than it was. (p. 414)

P: اين اجازه هم با لحني دلبذير صادر شد و باتريج وجوان

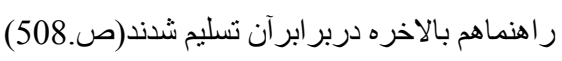

3.1.3.3 To have + (a) + good + aforesaid nouns has translated into an adjective.

For example:

E: had so much with and good breeding (p. 522)

P: خيلي خوش مشرب و با تربيت (ص.733)

3.1.3.4 Good + aforesaid nouns + -ed has been translated into an adjective. In Persian these equivalent adjectives may be simple or compound adjectives.

For example:

E: good - natured accident (p. 308)

P: رويدادي شيرين (ص.369)

E: she is a very friendly, good - natured woman (p. 263)

P: اين زن بانويي است زودآثناوخوش طينت (ص.315)

3.1.3.5 Good + aforesaid nouns has translated into an adjective + noun.

For example:

E: with all the good humor he could master in his countenance (p. 506)

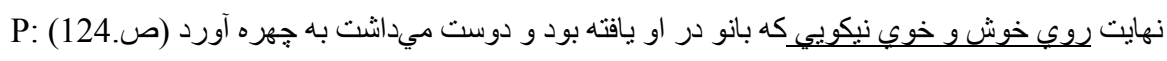

3.1.4 Idiomatic Phrases Containing the Word Good (10.94\% of all data are idiomatic phrases)

3.1.4.1 As Good As

For example:

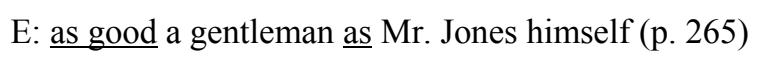

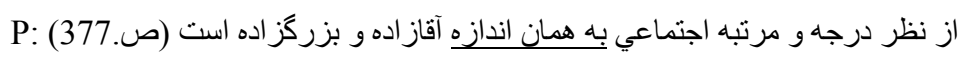

3.1.4.2 To Be As Good As (one's word)

For example:

E: he was as good as his words (p. 72)

P: به اين قول خود وفا هم كرد (ص.69)

3.1.4.3 To Be Good at Something

For example: 
E: I pray you are good at capping verses (p. 253)

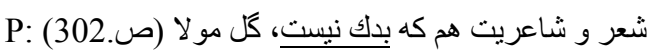

\subsubsection{To Be Good For}

For example:

E: but what is their fondness good for (p. 447)

P: ولي علاقه جه فايده دارد (ص.550)

3.1.4.5 To Be Good Enough for Some One

For example:

E: what ever happens to them, it is good enough for them (p. 119)

P: هر بلايي هم سرش بياد،حالا كاري نداريم،حقنشها(ص.129)

3.1.4.6 Many's the Good Time and Often

For example:

E: he hath injured any bed many's the good time and often (p. 58)

P: اينقدر بستر عفت منو آلوده كرده كه نكو و نبرس (ص.52)

\subsubsection{To Be Too Good to Some One}

For example:

E: oh, sir, you are too good to me (p. 73)

P: آه ، آقا، شما بيش از حد به من محبت ميكنيد (ص.70)

\subsubsection{To Have Some Good in Someone}

For example:

E: so you like wise have some good in you (p. 170)

P: تو هم جندان بي مصرف نيسني (ص.194)

\subsubsection{To Have Good Mind}

For example:

E: I have good mind to punish the rascal for being a coward (p. 243)

P: باوجوداين ميل دارح مردك را به خاطر بزدلي تنبيه كنم(ص.287)

\subsubsection{Good for Nothing}

For example:

E: I told him there were men that were good for nothing else but to be killed (p. 347)

P: بهش كفتم اينقدر آدم هستن كه فقط به درد كثته شدن ميخورن(ص.419)

3.1.5 This Category Involves Those Data in Which Good Has Not Translated (9.60\%)

For example:

E: even before I heard the good news. (p. 367)

P: حتي بيش از اينكه اون خبر به كَشم برسه (ص.443)

In the case of the word good, in almost more than half of the instances (59.50\%), it serves as an adjective. In about $17.30 \%$ of all cases in which good is an adjective, translator has used Persian equivalent "خوب". This means that almost in most cases (82.07\%) translator has rendered good into a typical and unmarked Persian equivalent. In nearly all cases $(92.58 \%)$ which the word good is a noun, translator has replaced good with a typical and unmarked Persian equivalent.

Generally we can say that the translator may $b$ translated according to context and collocational range, aimed at using established and typical equivalents. Good is a general word and the more general a word is, the broader its collocational range. As we know words rarely occur on their own; they almost occur in the company of other words. In a given language, certain words tend to co-occur regularly and as a result there are differences in collocational patterning both within and across languages. The important thing is the naturalness or the typicality of the resulting combinations. Differences in the collocational patterning of the source and receptor language can 
pose various problems in translation. So translators should bear in mind that what a word means often depends on its association with certain collocates and in different context. As far as translation is concerned, taking account of collocational meaning rather than substitution individual words with their dictionary equivalents is crucial. In fact a translator would be aiming at finding a collocation in the receptor language which conveys the same or similar meaning to that of the source collocation. In rendering unmarked source language collocation into the receptor language, a translator ideally aims at producing a collocation which is typical and natural in the target language while, at the same time preserving the meaning and effect associated with the source collocation; for example a "good/ bad law" is typically a "just/ unjust law" in Persian. It is important to keep in consideration that the use of common target-language patterns which are familiar to the target readers plays an important role in readability of translation and keeping the communication channels open, as the translator of The History of Tom Jones, a Foundling has done so.

\section{Discussion and Conclusion}

This research was an attempt to identify and classify the different equivalents of the English word good in the Persian translation of the English novel The History of Tom Jones, a Foundling. To accomplish the purpose of the study, the data were collected and then were analyzed. Analysis of the data showed that nearly in most cases which good served as an adjective or a noun, translator has used typical, familiar, natural and acceptable equivalents in Persian. As far as we know, this word is a general word both in Persian and English. Given the fact that general words have a broader collocational range than other words, it collocates with many words and according to the context in which they are, they may have different equivalents. Also we should take in consideration that collocations of lexical items will differ from language to language; In fact, in two languages the meaning is the same but different words are combined to indicate the meaning. Based on what is said above, it seems that translator according to the context and collocational range of the words which collocate with good has used common patterns of collocation in Persian. Indeed, it is worth mentioning that our sample was very small and the results of this study are confined to the aforesaid English novel, which is a literary work of eighteenth century, and its Persian translation. The same research on other works may produce different results and for generalization from the results more studies will be needed.

Although our sample was very small, it is hoped that its interesting findings produce practical assistance for translators, students of translation and anybody who is interested in translation studies field; furthermore, they are of major importance for pedagogical purposes in translation classes. These findings are:

1) Collocation is the most contextual factor for the translator.

2) As far as translation is concerned, translators should recognize the familiarity, naturalness and acceptability of a collocation and consider the acceptable collocational range of any lexical words.

3) Context and collocational range play a significant role in finding natural and common collocational patterning of the receptor language.

4) English-Persian dictionaries themselves are translations and their capability in term of presenting equivalents is subject to restrictions.

5) Translators should not entirely rely on dictionary equivalents.

6) Translators should not always translate good in "خوب". In different contexts, they should use suitable equivalents for them.

7) In the process of translation, translator should make use of the receptor language potentials and translation strategies.

\section{References}

Bell, T. R. (1991). Translation and Translating: Theory and Practice. London \& New York: Longman.

Bussman, H. (1996). Routledge Dictionary of Language and Linguistics, translated and edited by Gregory Trauth and Kerstin Kazzazi. London: Routledge.

Fielding, H. (1361). The history of Tom Jones, a Foundling, translated by Ahmad Karimi Hakkak. Tehran: Nilufar Publishers.

Larson, M. L. (1984). Meaning - based Translation: a Guide to Cross - Language Equivalence. London: University Press of America.

Merriam - Webster's Collegiate Dictionary, Eleventh ed. (2006). United State of America: Merriam- Webster Inc. 
Munday, J. (2001). Introducing Translation Studies: Theories and Application. London: Routledge.

Newmark, P. (1988). A Textbook of Translation. London: Prentice Hall.

Nida, E. A., \& Taber R. Ch. (1969). The Theory and Practice of Translation. Leiden: E.J.Brill.

Project Gutenberg. (2004, September). Ebook of The History of Tom Jones, a Foundling. Retrieved January 7 , 2008, from http://www.ibiblio. org/Gutenberg/etext 04 